\title{
The Indigenous Education and the Emergence Ethnic in Southern Brazil: An Approach from the State of Santa Catarina
}

\author{
Miguel Ângelo Silva da Costa ${ }^{*}$, Cláudio Luiz Orço², Mirian Carbonera ${ }^{3}$ \\ ${ }^{1}$ Postgraduate Program in Education, Universidade Comunitária da Região de Chapecó, UNOCHAPECO, \\ Chapecó, Brazil \\ ${ }^{2}$ Department of Human Sciences, Universidade do Oeste de Santa Catarina, UNOESC, Xanxerê, Brazil \\ ${ }^{3}$ Memory Center West of Santa Catarina, Universidade Comunitária da Região de Chapecó, UNOCHAPECO, \\ Chapecó, Brazil \\ Email: ${ }^{*}$ miguel.costa@unochapeco.edu.br
}

Received 1 March 2015; accepted 1 June 2015; published 4 June 2015

Copyright (C) 2015 by authors and Scientific Research Publishing Inc.

This work is licensed under the Creative Commons Attribution International License (CC BY).

http://creativecommons.org/licenses/by/4.0/

(c) (i) Open Access

\begin{abstract}
The condition of social exclusion is a feature among Brazilian indigenous communities. However, the consolidation of indigenous organizations and the provision of specific public policies, including those related to indigenous school education, has contributed to the emergence of ethnic indigenous collective in Brazil. Analyzing this social process in the State of Santa Catarina (Brazil), as well as their relation with the development of indigenous school education in South Brazil is the objective of this article.
\end{abstract}

\section{Keywords}

Indigenous Identity, Indigenous School Education, Santa Catarina, Brazil

\section{Introduction}

According to the International Work Group for Indigenous Affairs (IWGIA), headquartered in Copenhagen, it is estimated that, currently, divided at least into 5000 peoples, the global indigenous population exceeds 350 million people (IWGIA, 2011) ${ }^{1}$. It is evident that estimates vary over time and, in this case, it would be no exagge-

\footnotetext{
*Corresponding author.

${ }^{1}$ Founded in 1968, the IWGIA is an international organization, non-governmental, concentrating efforts in action/projects geared for Human Rights and the deconstruction of subordination of indigenous peoples around the world. Specifically, its actions are focused on research works, document production and dissemination of information, cooperation projects with organizations and Indigenous communities. For more details about the IWGIA, access: <http://www.iwgia.org/index.php>. Acessed in: April 5th, 2012.
}

How to cite this paper: da Costa, M. Â. S., Orço, C. L., \& Carbonera, M. (2015). The Indigenous Education and the Emergence Ethnic in Southern Brazil: An Approach from the State of Santa Catarina. Creative Education, 6, 855-866. 
ration to say that variables, such as the constant threat of territorial invasion and murders, the plundering of their resources, cultural and legal, as well the discrimination and even the lack of acceptance suffered, may involve the social invisibility process of indigenous peoples, if not the inherent denial of their identity.

In Brazil, for example, until the mid-1970s, the disappearance of indigenous peoples showed up inevitable. Until then, the Indian policies, completely linked to the assimilationist paradigm of that time and the ruling developmentalist ideology, unlike preserve culturally and socially these social groups, remained strongly subordinate to infrastructure works, the construction of roads and hydroelectrics, as well the process of expansion of farms and mineral extraction on Indian lands over the national territory.

From the early 1980s, however, the social reality of these peoples began to change. Although some indigenous groups have diminished demographically and even experienced the harsh threat of extinction, the performance of the first movement of indigenous social organization and their seeking to defend their interests contributed to the reversal of the demographic curve of this population in the country. Process that, according Gersem dos Santos Luciano (2006: p. 28), finds its anchor in a phenomenon known as "ethnogenesis" or "re-ethnicization".

Coined in the epistemological field of anthropology, the term ethnogenesis has been used to describe different social processes perpetrated by the "resurgence" of ethnic groups. According to Miguel Alberto Bartolomé (2006: p. 40), in general, the concept was born as a tool to describe the development, throughout history, human collectivities that we named ethnic groups, to the extent that they perceive themselves and are perceived as distinct formations from other groupings by exclusion. That is, for this mexican anthropologist, the concept was coined in order to realize the historical process of setting up ethnic groups, mediated result of migrations, invasions, conquests, fissions or fusions. However, as warns Bartolomé (2006: p. 40), more recently, also became engaged in the analysis of recurrent social emergency processes and the political groups traditionally subjected to relations of domination.

In last instance, paraphrasing Miguel Bartolomé (2006: p. 46), we can even say that:

[...] the ethnogenesis was and is an ongoing historical process that reflects the cultural and political dynamic of the past or exterior societies of the development of nation states today. It is the basic process of setting and structuring of human cultural diversity, where their roots merge in millennia and they stick up into the present.

Though the condition of social exclusion is a striking feature among Brazilian indigenous communities, the consonance between creation and consolidation of formal indigenous organizations, as well as provision of specific public politics, including those related to indigenous school education, and has contributed increasingly more contributed to the process of emergence of these ethnic social groups in Brazil. Put into screen the effects of a process that has contributed to the magnification of indigenous social visibility, thus as their relation to the structural development of differentiated education in the state of Santa Catarina is the purpose of this article.

That being so, initially, we could ask how does it become possible to put on the screen the emergence of the indigenous population in Santa Catarina? One of the strategies that we use for this was the macroanalytical observation of the variation of the self-declared indigenous region. Evidently, the charge would not be the most simple, mainly due to the still low producing of specific work about the issue in Santa Catarina. In this sense, data from the latest census, conducted by the Brazilian Institute of Geography and Statistics (IBGE) in 2010, they become of great value to the enterprise that, in the following pages, we now share with our potential readers.

\section{Demographic Emergence of the Indigenous Population in Santa Catarina}

According to Census data (IBGE, 2010), more than 230 indigenous peoples account currently for 817,963 individuals whose declare themselves as well in Brazil. Of these, 315,180 live in cities and 502,783 live in rural areas, which corresponds to approximately $0.42 \%$ of the total population of the country. Although, since then, the positive response in the demographic curve is continuous, the growth of indigenous self-declared in the period between 2000 to 2010 (11.42\%) was not as significant as that seen in the period between 1991 to 2000, when it reached the top of $149.59 \%$.

Unfortunately for this article writing, we do not have the census variables related to ethnicity, language spoken at home, among others elements related to the ethnicity of indigenous groups surveyed by the IBGE. These 
data would certainly help greatly to a better understanding as to the composition of the indigenous population and, consequently, its growth. Anyway, at the risk of generalization, it is possible to infer that in relation to the mosaic of large Brazilian regions, the data published by the IBGE's Board of Research (IBGE, 2012) indicate that the North, Northeast and Midwest regions show growth in the population volume of indigenous self-declared in the 2000/2010 period, of $43.3 \%, 22.5 \%$ and $25 \%$, respectively. Whereas the Southeast and South regions have revealed population declines ranging from $39.2 \%$ to $11.6 \%$, respectively Table 1 .

Regarding the situation of domicile, according to data from the census references of 1991, 2000 and 2010, the observed absolute variation from 2000 to 2010 reveals that in urban areas there was a decrease of indigenous self-declared in Brazil as a whole, being the North region the only, practically, revealed that upward growth. In the rural áreas, Brazil grew in 151,900 indigenous, corresponding to 43.3\%. Among major regions, the North was also presented the highest growth-77,000 indigenous, or $46.2 \%$ - while the Southeast was a decrease of almost two thousand indigenous in the period 2000 to 2010 (IBGE, 2012).

Still on the spatial distribution of the self-declared indigenous revealed by 2010 Census, the North region and the Amazon environment maintained supremacy over the Census, with $37.4 \%$ of the self-declared. According to analysis of the spatial structure, differently that observed for the 2000 Census, reducing the number of people who self classify generically as indigenous in the 2000 Census can be attributed to the lack of identification of variables related to specific ethnic groups in the Census. Another possible conjecture is that a significant reduction of the participation of indigenous peoples in Southeast region is related to the migratory phenomenon of return to their lands; however, as in the case of ethnicity-related variables, the data related to migration are not yet available for consultation at the IBGE site. Furthermore, we consider that, in general, to the Southeast and South regions, both in urban and in rural area, there was a reduction in the total participation of indigenous people in the country's total indigenous (Table 2) (IBGE, 2012: p. 9).

Regarding the analysis of the Units of the Federation, Amazonas state has the largest self-declared indigenous population of the country, with 168,700 (20.6\%); the state with the lowest number was Rio Grande do Norte, with 2500 (0.3\%). Except the state of Amazonas, which has self-declared indigenous population exceeding 100

Table 1. Absolute growth of the indigenous population declared, by large regions-Brazil (1991-2010).

\begin{tabular}{cccccc}
\hline & \multicolumn{5}{c}{ Large Brazilian Regions } \\
\cline { 3 - 6 } Year & North & Northeast & Southeast & South & Midwest \\
\cline { 2 - 5 } & 124.615 & 55.853 & 30.589 & 30.334 & 52.740 \\
1991 & 213.443 & 170.389 & 161.189 & 84.747 & 104.360 \\
2000 & 305.873 & 208.691 & 97.960 & 74.945 & 130.494 \\
\hline
\end{tabular}

Source: Elaborated from IBGE data (IBGE, 2012).

Table 2. Relative participation of indigenous self-reported resident population, by domicile situation, considering the Major Regions (1991/ 2010).

\begin{tabular}{|c|c|c|c|c|c|c|c|c|c|}
\hline \multirow{3}{*}{ Major Regions } & \multicolumn{9}{|c|}{$\begin{array}{c}\text { Relative participation of indigenous self-reported resident population, by domicile situation, considering the } \\
\text { Major Regions (in percentage) }\end{array}$} \\
\hline & \multicolumn{3}{|c|}{ Total } & \multicolumn{3}{|c|}{ Urban } & \multicolumn{3}{|c|}{ Rural } \\
\hline & 1991 & 2000 & 2010 & 1991 & 2000 & 2010 & 1991 & 2000 & 2010 \\
\hline North & $42.4 \%$ & $29.1 \%$ & $37.4 \%$ & $16.8 \%$ & $12.1 \%$ & $19.5 \%$ & $50.5 \%$ & $47.6 \%$ & $48.6 \%$ \\
\hline Northeast & $19.0 \%$ & $23.2 \%$ & $25.5 \%$ & $22.5 \%$ & $27.6 \%$ & $33.7 \%$ & $17.9 \%$ & $18.4 \%$ & $20.4 \%$ \\
\hline Southeast & $10.4 \%$ & $22.0 \%$ & $12.0 \%$ & $35.4 \%$ & $36.7 \%$ & $25.1 \%$ & $2.5 \%$ & $5.9 \%$ & $3.7 \%$ \\
\hline South & $10.3 \%$ & $11.5 \%$ & $9.2 \%$ & $14.3 \%$ & $13.6 \%$ & $10.8 \%$ & $9.0 \%$ & $9.3 \%$ & $8.1 \%$ \\
\hline Midwest & $17.9 \%$ & $14.2 \%$ & $16.0 \%$ & $11.0 \%$ & $10.0 \%$ & $10.9 \%$ & $20.1 \%$ & $18.8 \%$ & $19.1 \%$ \\
\hline
\end{tabular}

Source: Elaborated from IBGE data (IBGE, 2012). 
thousand, in most units of the federation (15) this population lies in the range 15 to 60 thousand of indigenous. (IBGE, 2012).

However, it is worth observing that, in the relative participation of the total population of the units of the federation, Roraima is the state that holds the highest percentage, $11 \%(49,637)$. Besides Roraima, only five units of the federation have self-declared indigenous population above 1\%: Amazonas 4.8\%; Matogrosso do Sul 3\%; Acre 2.2\%; Mato Grosso 1.4\%; and Amapá 1.1\%.

Reducing the scope of analysis for Meridional Brazil (Paraná, Santa Catarina and Rio Grande do Sul), where the decline of the indigenous population recorded was 9802 or $11.6 \%$, Paraná state was the unity of the region who attested the largest decrease.

When comparing the 2000 and 2010 census references, we verify that the resident Indian population decreased in Paraná about 17.7\%. In other words, while in the 2000 Census about 31,488 Paraná citizens declared themselves indigenous, in 2010 that number dropped to 25,915 equivalent to $0.2 \%$ of the registered population at the last census in the state $(10,444,526)$. In Paraná, the largest indian reservation is Rio das Cobras in Nova Laranjeiras. The city of 11,000 inhabitants is precisely the one that has the highest percentage of self-declared indigenous, composing its population, between the municipalities of Paraná: 19\% of the inhabitants, 2,239 people, from Nova Laranjeiras declared themselves indigenous. Then is Manoel Ribas City, with 12.9\% of indigenous population (1699 people) and Tamarana City, with 12.1\% (1483 people) (IBGE, 2012).

In the state of Rio Grande do Sul, in 10 years, the self-declared indigenous population decreased 5,700 people. If in 2000 the population so self-declared totaled about 38,718 people, in 2010 it decreased to 32,989 people, which, in percentage terms, representing a decrease of $14.08 \%$, according to data provided by the Research Board of the IBGE. In general, we can say that while the total Indians living in Rio Grande do Sul represent 4.03\% of the Indians of Brazil, people who declared themselves as indigenous in the IBGE survey represent $0.3 \%$ of the state population, which was about 10.6 million people in 2010 . The number of Indians living in Porto Alegre (the state capital) also decreased from 6,356 in 2000, to 3308 in 2010. During the period, there was a decrease in the population of Indians established in cities, while there was growth of rural residents. The largest Indian reservation in Rio Grande do Sul is the TI Guarita-Redentora (Gonçalves, 2010). Located in the northwestern part of the state, in the Tenente Portela (1997), Redentora (4033) e Erval Seco (209) municipalities, the reserve is home to the largest indigenous population of this federal unit. Among other municipalities with outstanding indigenous presence in Rio Grande do Sul, We can also highlight the Charrua (1524), Viamão (1065), São Valério do Sul (1044), Ronda Alta (1028), Planalto (1016), Benjamin Constant do Sul (1003) e Cacique Doble (929) (IBGE, 2012).

In Santa Catarina, in the region which incorporates this article, unlike the states of Paraná and Rio Grande do Sul, the self-declared indigenous population grew. The census conducted in 2000 indicated that the state accounted for 14,542 indians. In 2010, the absolute self-declared indigenous population increased to 16,041, an increase of $10.3 \%$. Before that, however, the census conducted in 1991 testified that the population which selfdeclared indigenous in Santa Catarina totaled only 4883 people, but with an increase of self-declared as well, which came up to 198\% (IBGE, 2012).

Based on information provided by IBGE, data regarding Santa Catarina reflect the same trend in other regions of the country. There is, therefore, a significant increase in the self-declared indigenous population between 1991 and 2000 and some stability in the growth rate in the next period. However, it is worth asking about the spatial distribution of this population in the state.

In general, we can say that the TIs in the region are characterized as small territorial extensions, but with high population density, which negatively affects the quality of life of this population self-declared as well. Pausing in the 20 micro-regions of the state, we realize that five (05) of them had more than 1000 self-declared indigenous individuals. In ascending order, they are: Joinville microregion, with 1315, or 8.20\% of the total population self-declared as well; Rio do Sul microregion with 1549 (9.66\%); Chapecó microregion with 1613 (10.06\%); Florianópolis microregion with 2185 (13.62\%); and the Xanxerê microregion with 4625 (28.83\%). In relation to the five major population concentrations, according to the total population of the state microregions, also in ascending order, we find the following estimates: Florianópolis microregion (0.25\%); Chapecó microregion (0.39\%); Tijucas microregion (0.4\%); Rio do Sul microregion (0.76\%); and Xanxerê microregion (2.94\%) (IBGE, 2012).

There are no data to identify, nor to accurately quantify the spatial distribution of the self-declared indigenous population in the state, according to their ethnic self-identification, or, if you will, their self-identification identity. But as we know, the spatial distribution of these groups is closely related not only, but also the historical 
dynamics of these ethnic groups and its correlation with regional setting. Or rather, the processes triggered by migrations, invasions, conquests, survival strategies, among other aspects related to the historical shaping of social and territorial space of Santa Catarina, because, as stated by Sílvio Coelho dos Santos (2007: p. 159), would be too fanciful to think that Brazil, in general, and Santa Catarina, as part of the cultural mosaic that makes up the country, it were "cordial". The violence has always been present in everyday social relations and, in particular, as a way of silencing these social groups.

As a result, to better understand the current spatial distribution of indigenous self-declared in the state, it seems fruitful to accomplish what we might call the indian mapping socio-historic in Santa Catarina.

\section{Indigenous Socio-Historical Cartography in Santa Catarina}

We can say that from the point of view of ethnic, indigenous people in Santa Catarina is divided into three major ancestral groups: the Guarani, Xokleng e/or Laklãnõ and Kaingang. The Kaingang are the majority in the state, with a population of 6397 individuals, Xokleng totaled 1849 and Guarani, 1189 individuals (Siasi-Funasa/MS, 2012).

Comparing the 2010 Census data with those provided by the Information System for Indigenous Health Care \{Sistema de Informação da Atenção à Saúde Indígena (Siasi-Funasa/MS)\}, we perceive a significant variation between them. One response to this variation of approximately 6,606 individuals, between one and another database, that is, most probably, SIASI data collection has focused on the villages of Indigenous Lands (TI's) of Santa Catarina, while the IBGE data extrapolated this universe. Thus, we can to infer that, in 2010, possibly 9435 individuals self-declared indigenous lived in TI's in Santa Catarina: the Kaingang (TI Xapecó, TI Toldo Chimbangue, TI Toldo Pinhal, Condá Indian reservation); the Guarani (TI Cachoeira do Inácios, TI Mbiguaçu, TI Morro Alto, Tekoa Araça'í-TI Xapecó and Tekoa Taquaty—TI La Klaño); and the Xokleng (TI La Klaño). (Siasi-Funasa/MS, 20 abr. 2012). But others 6,606 or 41.18\% of 6,041 individuals surveyed by the IBGE in the same year, lived distributed outside of the TI's in urban areas or even in rural áreas of other municipalities.

Historically, the Guarani indigenous population occupied a territory that included from the São Paulo state coast, through practically the entire southern region, extending to much of Argentina, Uruguay and even a wide territorial range of Paraguay. Indeed, it is a country where even today the Guarani language shares space with Spanish, especially in the social space of rural communities. However, even if it belongs to the Tupi-Guarani language family, of the Tupi branch, the Guarani did not make up a homogeneous population in terms of language. Roughly speaking, we can say that basically divided into three groups: Mbya, Ñandéva and Kayová (Langer \& Cemin, 2003).

In Santa Catarina, traditional occupants of the coast, where they were identified by the first waves of conquerors as the Carijós, there is a predominance of Guarani Mbya and Ñandéva indians. According to the anthropologist Silvio Coelho dos Santos (2007), there are reports that, in the early seventeenth century, the indigenous population on the coast of Santa Catarina reached about one hundred thousand people ${ }^{2}$.

According to Maria Dorothea Post Darella (2007), during the centuries that followed, the Guarani population chose not to halt relations with non-Indians, taking refuge in the woods closed niches that existed between the urban agglomerations and agricultural frontiers. But both cities as the agricultural frontiers expanded, making spaces with favorable characteristics for the Guarani occupation increasingly tight (Darella, 2007: pp. 9-10). "Even seeming exaggeration, in order to disregard the backstory involving contact situations, it is noted that it was from the mid-twentieth century that the Guarani's felt the hardest impact of the relationship with encompassing society process” (Darella, 2007: p. 1).

This for example is the case of the western region of Santa Catarina, where the registration of indigenous presence, more specifically the Mbiá Guarani date longtime (Kern, 1994: p. 104). However, because of the great spatial mobility, characteristic of this group, becomes difficult to determine their population niches more effective in the process of setting the state of Santa Catarina. Also, perhaps the main difficulty resides in a certain "masking" of Guarani in the official documentation of that period, mainly in the western region of the state, due to the configuration of the agrarian structure in that region. With the legal and administrative structures subordinated to the interests of local settlers, merchants and industrialists of European descent, advancing western frontier was guided by practices in which members of the dominant society ended titrating to themselves huge

\footnotetext{
${ }^{2}$ Organized into subgroups and distributed in several villages, the Carijó they lived sedentary way and dominated horticultural techniques,
} hunting, collecting, pottery, basketry, spinning cotton, addition to being deeply connoisseurs of relief, local flora and fauna (Santos, 2007). 
tracts of land, with the exclusive and sole purpose of profiting from the resale to colonizing companies or directly to the colonists. These practices contributed directly to the land traditionally owned by Indians passed into the hands of rural producers (Langer \& Cemin, 2003).

This is precisely what Silvio Coelho dos Santos (2007: p. 34) makes us think when he observed that, in relation to the process of land dispossession of the native population, by the "pioneers" fronts arriving in Santa Catarina, “[...] the mestizo and the Indian came out of the land in which companies were interested, by force of weapons of the hired gunmen, or the presence of justice and police, constantly manipulated by entrepreneurs or the acquisition of improvements by entrepreneurs".

Still on the Western Santa Catarina, we can consider that, despite the inability to resist and defend their lands, Guarani sought ways to survive dispersing or seeking refuge in the territories of other indigenous groups, which led them, during a long time, to share social spaces on Xokleng and Kaingang lands.

In general, across the region, the presence of this indigenous group is verified in many municipalities of Santa Catarina. Among some of them are Palhoça, Biguaçu, Guabiruba, Itajaí, Navegantes, Araquari, Joinville, Barra do Sul, São Francisco do Sul, Joinville, Passo de Torres, Garuva, Treze Tílias, Cunha Porã, Ibicaré, Itapiranga, Dionísio Cerqueira, Guaraciaba, Barra Velha, Jaguaruna, Araranguá, Guaramirim, among others (Santa Catarina, 1998: p. 87).

On the coast of the state, where the presence of ethnic Guarani is greater, There are 18 villages, among which, from the south to the north: Morro Grande, Marangatu, Massiambu, Morro dos Cavalos, Cambirela, Mbiguaçu, Amâncio, Amaral, Itanhaen, Canelinhas, Tarumã, Piraí, Jabuticabeiras, Pindoty, Conquista, Reta, Morro Alto and Yakã Porã.

In general, we can say that the Guarani Mbyá represent a portion of the self-declared indigenous population in the region, that keeps displacements toward the coastal region, in search of land they still have the Atlantic Forrest to live. Such movement has always directs to the known "traditional" territory, passed on from generation to generation. However, despite the establishment of new villages, the old ones are never entirely abandoned (Darella \& Litaiff, 2000).

The Xokleng indigenous group, the majority of which recently came to call themselves Laklãnõ, is reminiscent of semi-nomadic groups of the Jê linguistic branch, occupying the slopes of mountains, the coastal valleys and the edges of the southern highlands of Brazil (Langdon \& Wiik, 2008: p. 174). For these authors, the Xokleng name gained expression due to the identification of non-Indians, particularly anthropologists, since the Indians themselves had no specific term of self-designation, although they differed from the Kaingang e Guarani-neighboring groups with whom vied territory since the expansionary process of national society, getting regionally known as Botocudos and more pejoratively, as Bugres (Langdon \& Wiik, 2008: p. 175).

The most effective interaction of this group with the surrounding society in the current state of Santa Catarina's territory dates back to the Brazilian Imperial period. We're not saying, therefore, that until then the Xokleng have remained isolated, but that was from the arrival of the first waves of European immigrants to the region (by 1829) this ethnic group came to live with greater intensity the effects of the expropriation of the vast territory they occupied process.

The first waves of European immigrants who arrived in Santa Catarina coast settled in São Pedro de Alcântara, locality near Florianópolis. During certain period the land that mattered to the government of the province were located between the coast and the highlands. Valleys with dense vegetations were considered inhospitable and uninhabited regions, although it has long been known from the indigenous presence there. Before 1850, however, the colonies were already settling into the Xokleng traditional territory, but it was only after the beginning of that decade, with the founding of the colony of Blumenau and Joinville (1851), that indigenous passed, increasingly feeling the effects of the expropriation of their traditional territories (Santos, 2007).

Victims of relentless action of "bugreiros" (armed groups organized by the imperial and provincial governments) and diseases such as influenza, measles, pertussis, pneumonia, sexually transmitted diseases, among others; what remained of the Xokleng underwent profound changes in their eating and cultural habits. But not only that: in the 1970s, the construction of the North Dam, in José Boiteux, and the opening of the haul road within the area emphasized the exploitation of natural resources (heart of palm and hardwood), which led to serious consequences for the already difficult living conditions of the Xokleng population established that microregion (Santa Catarina, 1998: p. 88).

Concerning the delimitation of a specific area, in 1926, the Duque de Caxias Indigenous Post was created by the Governor of the State of Santa Catarina, Adolfo Konder, which allocated to Xokleng's a portion of land equivalent to 20,000 hectares, which later would become the Ibirama Indigenous Land-La Klaño. In 1965, was 
officially demarcated an area of 14,156 hectares. According to Langdon \& Wiik (2008: p. 174), Currently it is estimated that there are about 1500 individuals grouped in the Ibirama Indigenous Land, which has also been, in recent years, designated by the Indians as Laklãnõ Indigenous Land.

Located in the Upper Valley of the Itajaí River region, about 260 kilometres northwest of Florianópolis, the approved area is entered in the José Boiteux, Vitor Meireles, Itaiópolis and Doutor Pedrinho municipalities. About 70\% of the area of indigenous land is within the boundaries of the José Boiteux (southwest of the indigenous land) and Doutor Pedrinho (northern of the indigenous land) municipalities. From the point of view of the natural space, the La Klaño Indigenous Land extends along the Hercílio River and several of its tributaries, as Toldo and Plate, and frames one of the many valleys constituents of the great basin of the Itajaí-Açu River. The watershed of the Itajaí-Açu River, also called Itajaí Valley, covers 15,000 square kilometres of Santa Catarina state where 52 cities are located (Wiik, 2001).

Until the mid-1970s, before the construction of the North Dam, there was just one village. In 2000, villages in Indigenous Land passed to five and in 2004 could already register seven. Currently, the existing villages within the La Klaño Indigenous Land are: Bugio, Sede, Figueira, Palmeira, Coqueiro, Toldo and Pavão. They are all linear, extending along the valleys of the Hercílio, Plate and Toldo Rivers (Scopel, 2005).

Again quoting Langdon \& Wiik (2008), one of the characteristics of this indigenous ethnic group consisting of cooperation and production based on the extended family social unit or domestic groups. However, once hunters and gatherers, Xokleng are today surviving on subsistence farming and harvesting; productive activities, as seasonal laborers in the region, service providers to local settlers, merchants of wood; as employees of public agencies, such as Funai and Funasa, besides the pensions for the elderly, assistance state projects and philanthropy. Also worth to note that the craft production can be considered a resource for Xokleng families, whereas, although minimal, is an input for the community (Langdon \& Wiik, 2008: p. 175).

Distributed by the Rio Grande do Sul, Santa Catarina, Paraná and São Paulo states, the Kaingang form one of the largest indigenous groups that have survived in Brazil. According to Kimiye Tommasino (2001), before and even in the early days of contact, each local kaingang group had its own sub-region, with the right to exploit it, according to culturally determined rules. Visits between relatives of different local groups were frequent, and reception (the banks of rivers) was performed ritually. Therefore, as this anthropologist, a Kaingang society was distributed in various local groups forming subterritories who were socially connected, and each group had its exploration area, fact that refers to the existence of a legal code and for a specific concept of Kaingang land property, distinct from the capitalist concept of private property (Tommasino, 2001: p. 195).

Everything indicates that the traditional Kaingang's territory was formed by an area between the Uruguay and Iguaçu rivers. However, as the colonial interests facilitated, in the seventeenth century, the annihilation of the Guarani people, villagers by the spanish Jesuits, the Kaingang could expand to the north and south of those rivers, thereby achieving temporarily, the domain of the fields of the highland across the southern (D'angelis, 1989: pp. 16-20).

This process has intensified since 1728, when it opened a trail (road) linking the Morro dos Conventos in the south of Santa Catarina to the fields of Lages and Curitiba. The path passed to allow troops of cattle in Rio Grande do Sul were taken directly to the fairs of São Paulo. Due to this trade, highly stimulated by the height of the operation of the mines, arose the Lages Village, in 1771. But this same cattle trade existing loose in the fields of South also increased interest from traders of cattle in southern Brazil and gradually cattle herds have become the economic reason of national contingents, who started to compete with the Kaingang the dominance of fields located on the highland (Orço, 2008: p. 45).

Alongside the disputes over land ownership, sectors of the expansion front undergone indigenous to a continuous process of social and cultural disintegration. The utilization of indigenous as labor quickly dismantled tribal economic system, with direct impact on all other aspects of society, as an autonomous entity. The same occurred as a result of the sexual use of indigenous women. Contamination of the group, with diseases until then unknown to the natives, and for which they did not have any biological resistance, with the possibility of continuing to live independently (Tommasino, 2001).

Amid the social confrontations between indigenous and non-indigenous community, Kaingangs lost control of the land they needed as a basis for the sustenance of the components of their community, letting them be next to farms, subject to the orders of landowners (Orço, 2008).

Kaingangs continued subject to contingencies arising from the advancing fronts of the national society expanding. The misery experienced by groups Kaingang did not end with the implementation of SPI (Indian Pro- 
tection Service) in 1910. The lands occupied by Indians continued to be contested and used by representatives of the national society. The final demarcation of most of the areas occupied by indigenous people was always lengthy, full of agreements and concessions. In 1941, during the guardianship of the SPI (Indian Protection Service), the Xapecó Indian Post was created. Initially, it was called the Dr. Selistre de Campos Indian Post, standing in the region that was formerly known as Campo de Palmas, located in the West of Santa Catarina, in the current municipality of Ipuaçu.

In the late 1940s, several settlers, especially descendants of Italians, began to settle in the surrounding area of the then Xapecó Indigenous post. In the condition of leaseholders settlers, they drew on the exploitation of indigenous labor in rural production and logging. Since the creation of the Xapecó Indigenous Land, Kaingang population established in this area, well as in areas surrounding it, had to deal with many different strategies for exploiting their lands. It is true that many Indians settled there, what we might call a counterblow of lucidity, they sought to manipulate the rules of the game so that it was possible to survive strategically exploratory momentum. However, so deeply rooted to the violent acts of usurpation of their domains, or the misuse of natural resources on their lands, most of people remained more exposed to different trespasses (Piovezana, 2007).

Demarcated in 1902, the Xapecó Indigenous Land is located in the Ipuaçu and Entre Rios municipalities. Even facing various difficulties, currently the Indigenous Land has an area whose length is 15,623 hectares, added to 660 hectares concerning to the Pinhalzinho and Canhadão plots, declared in 2007. According to Funasa data (2010), ive more than 5000 indigenous people in the area, which comprises 15 villages, some with more than one thousand residents, others with less than a hundred. More than half of the total population (2766 people) lives in the Sede e Pinhalzinho villages (Siasi-Funasa/MS, 20 abr. 2012). Social differences present in this context are visible. As an example, we can observe that in the Sede village, the houses are mostly made of masonry or wood, whereas in smaller villages, not far away, families living in canvas tents, without access to potable water or electricity.

In summary, we consider that, regarding the Santa Catarina state, the Kaingangs are located on indigenous lands of Xapecó, where there is also the presence of a small group of Guarani, in Ipuaçu, Entre Rios and Marema municipalities; in the Toldo Chimbangue indigenous land, in Chapecó municipality; in the Toldo Pinhal Indigenous Area, in Seara municipality; and in the Ibirama indigenous land-as mentioned in the Xokleng territory. They are also located in the Abelardo Luz municipality, which integrates the Palmas indigenous land, with headquarters in Palmas, Paraná.

Unfortunately, without more specific data, perform an accurate mapping of the ethnic distribution of the indigenous self-declared population in Santa Catarina becomes almost an impossible task. Still, the attempt to reconstruct the indigenous socio-historical cartography in the state gives us an abstract idea to a certain extent, it is true, but illustrative idea of the destruction of these ethnic groups in the State. On the other hand, even if the Funasa data (2010) allow to conjecture about the location of indigenous self-declared, data provided by IBGE allow to observe the existence of an indigenous spread beyond their territories in Santa Catarina. Currently, the population is distributed in 75\% of the municipalities of Santa Catarina. Of the 293 municipalities in the state, 220 of them in there is at least one indigenous self-declared person. It is worth reiterating that the 2010 Census data included not only the indigenous population established in indigenous land already demarcated, or in the process of demarcation and/or recognition. Hence the most significant dispersion of population group by geographic area of the state.

Anyway, even if there are visible signs of this indigenous dispersion in the current Santa Catarina territory, the data analysis of the 2010 Census allows us to say that $50 \%$ of the total universe of so self-declared indigenous are concentrated in only 2.4\% (7) municipalities: Ipuaçu, with 21.42\% (3436); Chapecó, 9.07\% (1455); Florianópolis, 6.41\% (1028); José Boiteux, 5.51\% (884); Entre Rios, 3.87\% (620); Joinville, 3.26\% (523); e Vitor Meireles, 2.69\% (431).

If until here, based on demographic analysis, we intend to demonstrate the demographic emergency and the location of the indigenous population in Santa Catarina, the following pages our goal is to put on display not only the structure of indigenous education in the state, as well as its role in the process of (re) emergence ethnic of these social groups in the region.

\section{The Indigenous Education and the (Re)Emergence Ethnic in Santa Catarina}

In the state of Santa Catarina, the long process of institutionalization of indigenous education began in the 1960 s. 
However, were almost three decades later, conjunction with the FUNAI restructuring, that the Secretary of State/SED-SC expanded its direct involvement in the debate on the issues of education, in the spectrum of indigenous groups established in the state.

We can even say that it was from 1991, or better, in the wake of the Presidential Decree 26/91, whose resolution assigned to the Ministry of Education the function to coordinate actions related to indigenous education, and this, in turn, attributed the development of these actions to the state and local departments of education, the debate about the indigenous education gradually began to gain greater prominence on the agenda of educational policies in the region (Santa Catarina, 1998: p. 90).

Officially established in 1996, as the name itself indicates, the Center for Indian Education (Núcleo de Educação Indígena-NEI) became the agency responsible for proposing educational guidelines and for the establishment and implementation of school education which embraced the principles of specificity and difference, interculturalism and bilingualism, guaranteed in the Federal Constitution of 1988, recognized to the Indians their right to social organization, customs, languages, beliefs and traditions (Article 231), and ensured indigenous peoples the use of their mother languages and their own learning processes (Article 210). This right of use of the mother tongue and own learning processes is confirmed in the Constitution of the State of Santa Catarina, in the article 164, § 2nd (Santa Catarina-SED, 2005: p. 25) ${ }^{3}$.

In dialogue with the LDB No. 9.394/1996, especially with articles 32, 78 and 79, which point to the elementary and secondary school curriculum, specific and differentiated for indigenous peoples, to guarantee the use of the mother language and their own learning processes and the development of teaching and research programs to offer bilingual and intercultural education, the Complementary Law No. 170 (Law of the Education State System of Santa Catarina), in its Article 31 and Chapter X, strengthened the regulatory guidelines aimed to the education in indigenous communities of Santa Catarina.

However, was the resolution of the Board of Basic Education (Conselho de Educação Básica-CEB) No. 03/1999 which set guidelines for the operation of Indian schools, pointing out the basic elements for the organization and relative autonomy to them, with guidelines for the Political Pedagogical Project, and ensuring priority to indigenous to the exercise of teaching in their schools and ensuring their education. In addition, established the competence of the states the establishment and regulation of indigenous teachers, with admission by specific competition. Postulated also, that teacher education training should be specific, whereas the states promote initial and ongoing education training of indigenous teachers.

The Center for Indian Education (Núcleo de Educação Indígena (NEI)) began operating articulated the determinations of the mentioned above federal and state laws, as well as the indications of the Ministry of Education's General Coordination of Indigenous Education, created by determination of Interministerial Ordinance No. 559 , from 04/16/1991, whose goal is to coordinate, to monitor and to evaluate the pedagogical practices of indigenous education in the country. In addition, based on the National Curriculum Referential for Indigenous Schools and the Curricular Proposal of Santa Catarina guidelines, particularly in the Indigenous Education document, which reinforces the importance of training indian teachers, and stimulate the production of literature in the native language ${ }^{4}$, the Center for Indian Education (Núcleo de Educação Indígena (NEI)) became an important mode of articulation, dissemination and implementation of institutional actions in indigenous communities in Santa Catarina.

Several actions contributed to the advancement of policies dedicated to indigenous education. In the specific case of Santa Catarina it was no different. The alignment of actions based on legal devices of brazilian law contributed to the ethnic, social and cultural diversity was gradually recognized as legitimate in this state. Even if major advances are needed, both in a social and legal point of view, We can not help observing that indigenous struggles have enabled major achievements, especially the formal point of view.

By recognizing these achievements can not be thought of as mere concessions from the state or other social or political organizations, but as the effective of mobilization and collective actions which were turning into state policies, we also recognize the gradual process of "re-ethnicization" and emergence of indigenous groups as

\footnotetext{
${ }^{3}$ Art. 164. The complementary law organizing the state system of education shall fix, observed the law of guidelines and bases for national education, the minimum content for elementary and secondary education, in order to ensure, besides basic formation: $\S 2$ nd-The regular elementary school will be taught in Portuguese language, guaranteed to indigenous communities also the use of their mother languages and their own learning processes (Santa Catarina, 2009: p. 102).

${ }^{4}$ According to the 1998 document itself, Its formulation was intended to record the start of a journey dedicated "to join forces to overcome the exclusion of indigenous communities, ensuring them the right to the specificity and difference as well as access to cultural assets and materials produced historically” (Santa Catarina, 1998: p. 89).
} 
new social actors in the regional scenario.

But in terms of the structure of indigenous education in Santa Catarina, what real progress did the indigenous communities conquer? Leaving the exclusive plan of legal guarantees offered by the state and moving to the practical scope, what progress can be realized in a context of greater visibility and social affirmation of these ethnic groups in Santa Catarina?

The legal instructions, whether federal or state order, are explicit as to guarantee the indigenous rights to preserve their cultures, traditions, languages, social organizations, beliefs; finally, the right to live according to their culture and their free choices. More than this, the legal norms laid guarantee to the right to enroll in court in defense of their rights, overcoming the erroneous idea of civil disability of such individual and collective social actors (Luciano, 2011).

Although the idea of differentiated indigenous school be guided by methodological assumptions and the transmission principles generated, production and reproduction of knowledge of specific sociocultural distinct universes of each indigenous people, it also articulates to the necessary and desirable complementarity of acquiring knowledge and skills that go beyond the traditional knowledge of each people or community. Saying this means that the school and indigenous education have become an effective demand of indigenous peoples, up because they act as a complementary tool to the native pedagogies.

If for a long time indigenous peoples proved to be resistant or even indifferent to school and education, today have become protagonists not only by access to school and university, but also by actual conditions of school education (Luciano, 2011: p. 76). In the wake of this new context and in synchrony with policies aimed for reducing educational inequalities and respect to cultural diversity that the structure of indigenous education in Santa Catarina is gradually presenting positive effects.

In structural terms, we can say that increasing the number of school units is a sign of this positive reflection. If, in 2005, the state had 29 school units distributed in 18 areas of native settlements, currently it accounts for 43, which means that in seven years the indigenous education network expanded by 48.3\% (Inep, School Census 2005-2011). Although, as shown on Map 4, here is some dispersion of the indigenous population in the region, in all the higher concentration of that population niches there are indigenous education establishments.

In the specific case of the western region of the state, highlight the areas covered by the 5th and 4th Regional Offices of Education (Gerências Regionais de Educação-Gereds), headquartered in the Xanxerê and Chapecó municipalities respectively. At these two Gereds, are located 40\% (22) of the indigenous schools of Santa Catarina. Regarding the administrative dependence, is also within the space coverage of these two Gereds where there is a higher concentration both state (50\%) as municipal (77.78\%) schools (Inep, School Census 2011).

Besides the expansion of the school units, the enrollment also increased in the period between the years 2005 and 2011. If, in 2006, 1839 students were enrolled in indigenous schools, in 2011, that number grew 54.92\%, reaching thus 2843 enrollments. While in the Concórdia municipality (6th Gered) and Canoinhas (26th Gered) there was a decrease in enrollment, approximating $46 \%$ and $335 \%$ respectively, the enrollments in Joinville (23rd Gered), Florianópolis (18th Gered) and Xanxerê (5th Gered) presented growth rates equivalent to 169\%, 110\% and 67\% (Inep, School Census 2005-2011).

As regards the distribution of enrollments, according to the teaching modalities of basic education, the total enrollment of 2843 verified for the year 2011, 2244 (78.9\%) are in elementary school. The remaining 599, or $21.1 \%$ of the enrollments are distributed in other modalities of education offered.

Although the process of expanding school units dedicated to indigenous education in Santa Catarina, not all provide all modalities of education. Only on the 5th Gered (Xanxerê) all the modalities are offered. In the 6th Gered (Concórdia) and 26th (Canoinhas), only the elementary school is offered. Besides the 5th Gered, secondary education is offered at the 14th Gered (Ibirama) and the 18th Gered (Florianópolis). These Gereds that, in addition to high school and childhood education, like the 16th Gered (Brusque), also offer a modality of Young and Adult Education (EJA). In relation to special education, we found that only the 5th Gered, representing only 0.3\% of enrollments for the year 2011, it is offered (Inep, School Census 2011).

In general, we can consider that indigenous education in Santa Catarina, in Brazil as well, is permeated by discontinuous experiences, regionally unequal. Despite advances in the search for an ideal school, the challenge seems to be thinking of alternatives that might meet the most immediate needs. And this is not a unique reality for indigenous peoples, who constantly fight for the expansion of trading channels and for more continuous presence at the institutional level decisions. It is a reality shared by countless children, youngs, adults—students and/or teachers-who experience the everyday of Brazilian basic public school education. 
On the other hand, with the redefinition of the State and its traditional mechanisms of intervention, there have been changes in traditional patterns of political relations and, especially, the ways in which "people" relate to the might apparatuses. In this new dynamic of cultural and political interactions, new social movements guided by a policy of re-ethnicization also emerged. It would be no exaggeration to say that was exactly the identity factor and all the other factors hat converge in the process of ressignificating identities in the contemporary world that have led these new actors (individual or collective) to (re) group together in the same collective identity. The creation of the Union of Indigenous Nations in Brazil (UNI) and its consequent articulation with various world organizations is one example, whereas as observed by Roberto Cardoso de Oliveira (2006: p. 42),

From the almost pedagogical action that entity was able to accomplish with the indigenous peoples, especially in relation to self-esteem and recovery of their sense of dignity required for the Indian category, reviled throughout the history of interethnic contact, [...] Indians now began to assume their ethnic status with forums of a new citizenship that until then was practically denied to them.

The purpose of indigenous education implemented in Brazil represented an innovation in the educational system. It demanded adequacy of the institutions and agencies responsible, as boosted new dynamics, concepts and mechanisms, so that these schools were actually incorporated and benefited due to its inclusion in the official system as for social and cultural particularities were respected. But it also can and should be understood as a result of pressures, choices, desires and expectations of certain indigenous groups.

\section{Conclusion}

Several authors, among which we can mention Iara Bonin (1998), Rosa Helena Dias da Silva (2000), Mariana Kawall Leal Ferreira (2001), Gersem dos Santos Luciano (2006 and 2011), have highlighted that the education, at all levels and modalities, increasingly has been a desire of indigenous peoples. Although the conception of education is not uniform among these social groups, as noted by Gersem Luciano (2011: p. 72), "[...] the traditional education is no longer able to cope with the current indigenous life, increasingly dependent on national and global life, from the contact and interaction with the surrounding world”. Also according to Luciano (2011: p. 103), currently there are more than 8000 indigenous people who are at the brazilian universities, what means that "[...] the indigenous world is in the hallway, the door and inside the classrooms and laboratories [...]".

This is not about, evidently, a problem that can be depleted inside an article. However, we believe that social phenomena of demographic emergency and of (re)emergence ethnic of the indigenous collectivities in Santa Catarina, found strong echo in the wider dissemination and access to indigenous education. In other words, it means to say the process of (re)emergence ethnic of this population, should also be thinking of dialogical mode with their political demands, the expansion of the school education network and the policies developed by the State. It is no wonder that the search for implementation and for better conditions of indigenous education also appears in the wake of this historic process of social and ethnic emergence.

\section{References}

Bartolomé, M. A. (2006). Como etnogêneses: Velhos atores e novos papéis no cenário cultural e político. Mana. Rio de Janeiro, 12, 39-68.

Bonin, I. T. (1998). Professores indígenas: Resistência em movimento. Conferência ameríndia de educação, Congresso de Professores Indígenas do Brasil, Cuiabá: Secretaria de Estado de Educação/Conselho de Educação Escolar Indígena de Mato Grosso.

D’Angelis, W. (1989). Para uma história dos índios do Oeste catarinense. Cadernos do CEOM. Chapecó (SC), 4, 7-81.

Darella, M. D. P. (2007). Articulação política dos índios Guarani e projetos de desenvolvimento no litoral de Santa Catarina. Porto Alegre: VII RAM, UFRGS.

Darella, M. D. P., \& Litaiff, A. (2000). Os índios Guarani Mbyá e o Parque Estadual da Serra do Tabuleiro. Brasília: XXII Reunião Brasileira de Antropologia.

Ferreira, M. K. L. (2001). Antropologia, história e educação: A questão indígena e a escola (2nd ed.). São Paulo: Global.

Gonçalves, D. G. (2010). Biodiversidade e conhecimentos tradicionais associados: Um estudo da realidade kaingang e Guarani da reserva indígena de Guarita-redentora-RS. Master’s Thesis, Caxias do Sul: Universidade de Caxias do Sul.

IBGE (2012). Os indígenas no Censo Demográfico 2010: Primeiras considerações com base no quesito cor ou raça. Rio de Janeiro: Diretoria de Estatística. http://www.ibge.gov.br/indigenas/indigena_censo2010.pdf 
INEP. Instituto Nacional de Estudos e Pesquisas Educacionais Anísio Teixeira (2013). Microdados Censo Escolar (20052011). http://portal.inep.gov.br/basica-levantamentos-acessar

IWGIA (2011). Annual Report 2010. Copenhagen: Editora IWGIA.

Kern, A. A. (1994). Antecedentes indígenas. Porto Alegre: Editora UFRGS.

Langdon, E. J., \& Wiik, F. B. (2008). Festa de inauguração do Centro de Turismo e Lazer: Uma análise da performance identitária dos Laklãnõ (Xokleng) de Santa Catarina. ILHA: Revista de Antropologia, 10, 172-198. http://dx.doi.org/10.5007/2175-8034.2008v10n1p171

Langer, P. P., \& Cemin, V. (2003). Conflitos étnicos no Oeste de Santa Catarina: Diáspora e reagrupamento no Araçá'i. Cadernos do CEOM, 18, 243-260.

Luciano, G. S. (2006). O índio brasileiro: O que você precisa saber sobre os povos indígenas no Brasil hoje. Brasília: Ministério de Educação Continuada, Alfabetização e Diversidade: Rio de Janeiro: LACED/Museu Nacional, Volume 1. (Coleção Educação Para Todos).

Luciano, G. S. (2011). Educação para o manejo e domesticação do mundo entre a escola ideal e a escola real: Dilemas da educação escolar indígena no Alto Rio Negro. Ph.D. Thesis, Brasília: Universidade de Brasília.

Oliveira, R. C. (2006). Caminhos da identidade: Ensaios sobre etnicidade e multiculturalismo. São Paulo: Editora Unesp; Brasil: Paralelo, 15.

Orço, C. L. (2008). Educação indígena: Fronteiras culturais e inclusão social: Análise da Terra Indígena Xapecó. Master’s Thesis, Passo Fundo: Universidade de Passo Fundo.

Piovezana, L. (2007). Educação Escolar Indígena: Os Kaingang no oeste catarinense. Chapecó: Argos.

Santa Catarina (1998). Secretaria de Estado da Educação e do Desporto. Proposta Curricular de Santa Catarina:Educação Infantil, Ensino Fundamental e Médio. Temas Multidisciplinares. Florianópolis: COGEN.

Santa Catarina (2005). Secretaria de Estado da Educação, Ciência e Tecnologia. Documento base de orientação pedagógica/administrativa: Educação básica e profissional. Florianópolis: COGEN.

Santa Catarina (2009). Constituição do Estado de Santa Catarina 1989. Florianópolis: Assembleia Legislativa. http://www.alesc.sc.gov.br/portal/legislacao/docs/constituicaoEstadual/CESC_16_11_2009.pdf

Santos, S. C. (2007). Ensaios oportunos. Florianópolis: Academia Catarinense de Letras e Nova Letra.

Scopel, R. P. D. (2005). O agente indígena de saúde Xokleng: Por um mediador entre a Comunidade Indígena e o Serviço de Atenção Diferenciada à Saúde-Uma abordagem da Antropologia da Saúde. Master’s Thesis, Florianópolis: Universidade Federal de Santa Catarina.

SIASI. Sistema de Informação da Atenção à Saúde Indígena. Microdados. Fundação Nacional de Saúde. Ministério da Saúde. Brasil. http://sis.funasa.gov.br/siasi/

Silva, R. H. D. (2000). A autonomia como valor e articulação de possibilidades: O movimento dos professores indígenas do Amazonas, de Roraima e do Acre e a construção de uma política de educação escolar indígena. Cadernos CEDES, 19, 6275.

Tommasino, K. (2001). Terras indígenas Kaingang. Londrina: FUNAI/ISA. http://pib.socioambiental.org/pt/povo/kaingang/285

Wiik, F. B. (2001). Contato, epidemias e corpo como agentes de transformação: um estudo sobre a AIDS entre os índios Xokleng de Santa Catarina, Brasil. Cadernos de Saúde Pública, 17, 397-406. http://dx.doi.org/10.1590/S0102-311X2001000200014 